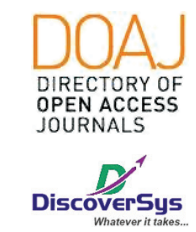

Published by DiscoverSys

\section{Efficacy of topical steroid therapy for phimosis treatment: a systematic review}

\author{
Andika Rendy, ${ }^{1}$ Arry Rodjani, ${ }^{1 *}$ Irfan Wahyudi ${ }^{1}$
}

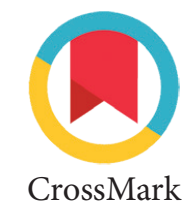

CrossMark

\title{
ABSTRACT
}

Background: Circumcision is the gold standard in the management of phimosis cases. Nowadays, there is some basic science research that showed topical steroid might be used to decrease the morbidity of phimosis cases. This research aims to determine which management is more effective in treating phimosis by using a systematic evidencebased medicine approach.

Methods: Literature searching was done to find journals that are deemed appropriate for these cases. We included 3 RCT studies in this review. Critical appraisal was conducted to determine the efficacy of topical steroid. We compared those two methods in managing cases of phimosis among children.

Results: Topical steroids effectively cause the preputium skin be soft and comfortable to retract. In several cases, some patients had difficulty to get retracted. For these cases, circumcision is needed. Conclusion: Topical steroid is effective in reducing the phimosis signs and symptoms, especially in patients who are younger and less than 3 years old. Further study and meta-analysis should be conducted in Indonesia to determine the effectiveness of this therapy in Indonesia.
'Departement of Urology, Faculty of Medicine Universitas Indonesia, Cipto Mangunkusumo Hospital, Jakarta

*Correspondence to: Arry Rodjani; epartement of Urology, Faculty of Medicine Universitas Indonesia, Cipto Mangunkusumo Hospital, Jakarta arry_rodjani@yahoo.com

Received: 2019-09-30 Accepted: 2020-01-06 Published: 2020-03-05

Keywords: Circumcision, phimosis, topical steroid

Cite this Article: Rendy, A., Rodjani, A., Wahyudi, I. 2020. Efficacy of topical steroid therapy for phimosis treatment: a systematic review. Intisari Sains Medis 11(1): 140-144. D0l: 10.15562/ism.v11i1.633

\section{INTRODUCTION}

Preputium is an area with specialised tissue that contains many nerve root endings. Anatomically, preputium covers the gland penis area. After the patient was born, this epithelial tissue will diffuse and sometimes causes difficulty in retraction. ${ }^{1}$ In 2-3 years, the front part of penis skin will leave off after the appearance of keratinised skin parts. Usually, this skin retraction happened after the keratinisation process that is followed with multiple erections. In around $75 \%$ of male below 3 years old, the skin retraction is not perfect. $^{2}$ However, there's a small percentage of patients has difficulty in retracting their skin.

The management of this condition Is usually with circumcision. Circumcision is a procedure that is often conducted on children. There are various indications for doing circumcisions such as religious indication and social indication. However, research showed that around $80 \%$ of neonates around the world does not practise circumcision. ${ }^{3}$

Phimosis is a condition that is most often appear in children and may be caused by many things. The most common etiologic is the lack of penis hygiene after birth. This lack of hygiene may cause fibrosis in the preputium ring that may cause significant retraction in the skin. ${ }^{3}$

Beside phimosis that is caused by many pathological causes. This phimosis can also appear physiologically. Physiologic phimosis can cause adhesion of epithelial cells in inside-part of the preputium into the glans-penis. This adhesion may disappear spontaneously where there's a retraction to the penis skin. This physiology phimosis will disappear spontaneously with ageing. ${ }^{4}$

Phimosis should be managed comprehensively. This phimosis that is not managed well by the medical doctor may cause disturbing complications such as paraphimosis. This paraphimosis is an emergency condition that should be managed as soon as possible. Paraphimosis may cause extensive inflammation and pain and may cause infarction/ necrosis and gangrene. ${ }^{4}$

Basic science research nowadays showed the potential of topical steroid drugs to reduce inflammation that appeared in the penis and may help the retraction. This review will try to find new literature about the usage of circumcision as an alternative to steroid topical in the management of phimosis cases that happened on the patients. According to the data above, we made the following clinical question based on PICO; In phimosis patients who have not undergone puberty $(\mathrm{P})$; is topical steroid (I); more effective than placebo $(\mathrm{C})$; in improving the patient's preputium retraction $(\mathrm{O})$ ?

\section{METHODS}

\section{Search Strategy}

The literature search was started on May $12^{\text {th }} 2016$ using 3 of the most common journal database: PubMed, Google Scholar and Cochrane database. The following Mesh search headings were used in 
the searching: 'phimosis', 'circumcision', 'topical steroid', and 'comparison study'. The strategy for study selection can be seen in Table 1 .

\section{Eligibility Criteria (Inclusion/Exclusion)}

Journal selection is based on inclusion and exclusion criteria. The inclusion criteria are clinical trials, i.e. randomised controlled trial (RCT), cohort, or case-control studies. The exclusion criteria are inappropriate types of study, such as experimental study, case report, or summary, and inadequate content or data. Abstract/full-text not written in English is also one of the exclusion criteria.

\section{Critical Appraisal of Studies: Quality Assurance Process}

Jadad scale was performed to assess the quality of all the studies..$^{5-7}$ It consists of 3 questions comprising randomisation (0-2 points), blinding (0-2 points), and withdrawals (0-1 points). For each question, 1 point will be given if the answer is "yes" and 0 point for "no". For question 1 and 2, additional 1 point is given if randomisation and double-blinding are described and appropriate. Otherwise, 1 point will be deducted from the total score. Studies with Jadad score of $>2$ are considered high quality, while $<2$ are considered low quality. ${ }^{5}$

The quality evaluation was conducted by two authors independently under those criteria. Any discrepancies were resolved by discussion and consulting the third author if necessary.

\section{Data Extractions}

The following data were extracted from each study: year of publication, design, intervention (drug \& dosage), sample size, follow up period, assessment of therapeutic effects, and result. An Excel form was used to elaborate on these data. Two authors were responsible for data extraction. Discrepancies were resolved through discussion or, if required, through consultation with the third person.

\section{RESULTS}

\section{Search Results}

From 3 databases (PubMed, Google Scholar, and Cochrane Library), we retrieved 35 studies written in English. However, after filtering for double journal, screening the abstract and title, and checking full-text availability, only 3 studies met the eligibility criteria to be included in this systematic review. There are 2 studies by Elmore et al. ${ }^{8}$ and Yang et al. ${ }^{9}$ which we excluded in this review after thorough consideration because of the inappropriate design of study (uncontrolled prospective study).

\section{Quality Assessment of Selected Studies}

The RCT by Esposito et $\mathrm{a}^{10}$ received full marks on the Jadad score (5 out of 5). The RCT studies by Letendre et al. ${ }^{11}$ and Lund et al. ${ }^{12}$ received Jadad score of 3 . The only missing point of these studies was that the method to generate randomisation was not described. No study possesses high risk of bias.

\section{Characteristics of Individual Study}

All of the studies are randomized placebo-controlled trial conducted between 2005-2009 in Canada, Italy, and Hong Kong. These studies enrolled 423 samples whose age ranging from 20 months to 15 years. Table 1 depicts the characteristics of each study.

\section{Efficacy Outcomes}

The first study is a randomised controlled trial conducted by Esposito et $\mathrm{al}^{10}$ in Italy. This research tried to compare the usage of mometasone furoate $0.1 \%$ cream to placebo cream. This placebo was used in 24 months. The researchers used the

Table 1 Baseline characteristics of studies

\begin{tabular}{|c|c|c|c|c|c|c|c|c|c|}
\hline \multirow[b]{2}{*}{ Author } & \multirow{2}{*}{$\begin{array}{c}\text { Year of } \\
\text { Publication }\end{array}$} & \multirow[b]{2}{*}{ Design } & \multirow{2}{*}{$\begin{array}{c}\text { Average } \\
\text { Age }\end{array}$} & \multirow[b]{2}{*}{ Intervention } & \multicolumn{2}{|c|}{ Sample size } & \multirow{2}{*}{$\begin{array}{c}\text { Follow up } \\
\text { period }\end{array}$} & \multirow{2}{*}{$\begin{array}{l}\text { Primary } \\
\text { Outcome }\end{array}$} & \multirow[b]{2}{*}{ Results } \\
\hline & & & & & Treatment & Control & & & \\
\hline $\begin{array}{l}\text { Esposito } \\
\text { et al }\end{array}$ & 2007 & $\mathrm{RCT}$ & $\begin{array}{c}4.7 \text { years } \\
(36 \text { mo- } 13 \\
\text { years })\end{array}$ & $\begin{array}{l}\text { Monometasone } \\
\text { furoate } 0.1 \% \\
\text { cream vs } \\
\text { placebo cream }\end{array}$ & 120 & 120 & $\begin{array}{l}4 \text { week, } \\
20 \text { month }\end{array}$ & $\begin{array}{c}\text { Fully } \\
\text { retractable } \\
\text { prepuce }\end{array}$ & $\begin{array}{c}65.8 \% \text { (topical } \\
\text { steroid) vs } \\
16.6 \% \text { ( placebo) } \\
\text { with } \mathrm{p}<0.0001\end{array}$ \\
\hline $\begin{array}{l}\text { Letendre } \\
\text { et al }\end{array}$ & 2009 & RCT & $\begin{array}{c}62 \mathrm{mo} \\
(20-184 \\
\mathrm{mo})\end{array}$ & $\begin{array}{l}\text { Triamcinolone } \\
0.1 \% \text { vs manual } \\
\text { retraction }\end{array}$ & 21 & 25 & $\begin{array}{l}8 \text { week, } \\
12 \text { month }\end{array}$ & $\begin{array}{c}\text { Retractile } \\
\text { foreskin (grade } \\
\text { I-II) }\end{array}$ & $\begin{array}{c}76 \% \text { (topical } \\
\text { steroid) } \\
\text { vs 39\% (placebo) } \\
\text { p }=0.0086\end{array}$ \\
\hline Lund et al & 2005 & RCT & $\begin{array}{c}6.7 \text { years } \\
(3-15 \\
\text { years })\end{array}$ & $\begin{array}{l}\text { Betamethasone } \\
\text { valerate } 0.1 \% \\
\text { cream vs } \\
\text { placebo cream }\end{array}$ & 66 & 71 & $\begin{array}{l}4 \text { week, } \\
8 \text { week, } \\
18 \text { month }\end{array}$ & $\begin{array}{l}\text { Improvement } \\
\text { of retractibility } \\
\text { score according } \\
\text { to } 5 \text { gradings } \\
\text { of phimosis. }\end{array}$ & $\begin{array}{c}74 \% \\
\text { (betamethasone) } \\
\text { vs } 44 \% \text { (placebo) } \\
\text { p }<0.01\end{array}$ \\
\hline
\end{tabular}



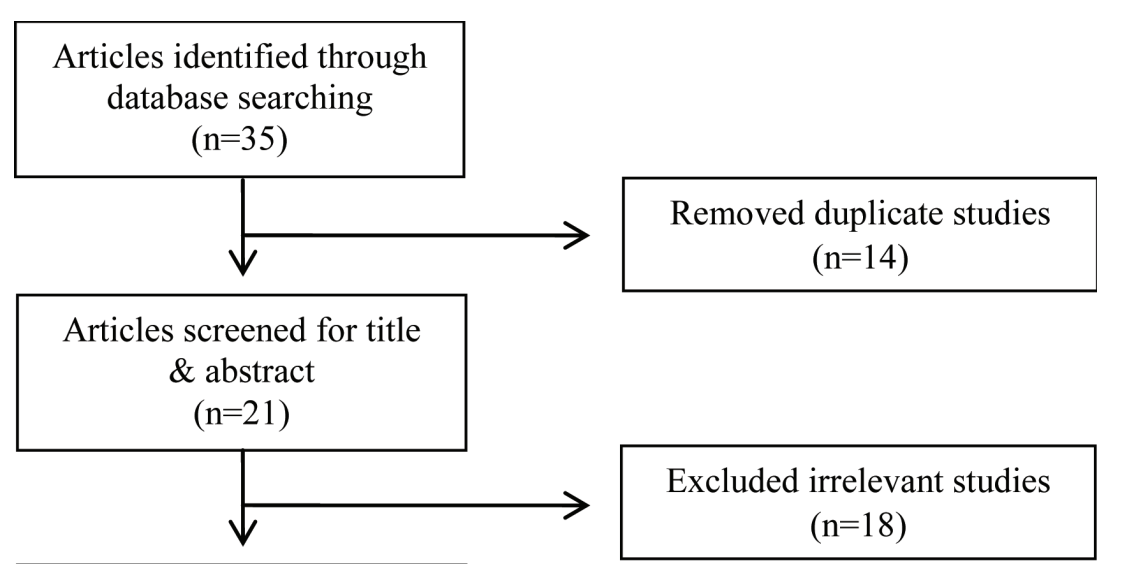

Full-text articles selected for eligibility $(n=3)$

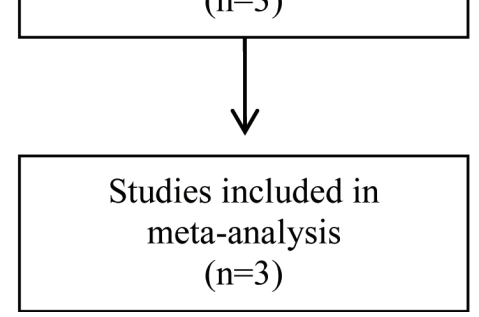

Figure 1 Flowchart of study selection process based on PRISMA guideline

mometasone furoate $0.1 \%$ cream on 120 patients with phimosis and placebo cream on 120 patients. In this study, the baseline characteristic of both groups at the start of the trial was similar. From the methodology, it can be observed that the therapy that is used mainly is topical steroid. It showed that in patients aged 6 to 30 months, the success rate of this therapy is $65.8 \%$. Mann-Whitney analysis showed that the result is statistically significant.

The second study was conducted by Letendre et al. ${ }^{11}$ in Canada. Latendre tried to assess the therapeutic effect of Triamcinolone $0.1 \%$ cream for grade III-VI phimosis compared to manual retraction with emollient cream. The sample size in this study is relatively small $(n=46)$. Initially, patients were instructed to use the blinded cream for 8 weeks. Parents or patients of both groups were also instructed to manually retract the skin as much as possible without discomfort twice daily. We can see that the author tried to avoid intervention and measurement bias by giving as similar treatment as possible to both groups. Circumcision was offered if topical steroid failed to achieve the desired response. After the first 8 weeks, $48 \%$ of the placebo group showed partial or total success and 52\% showed no response. On the contrary, $90 \%$ of the triamcinolone group achieved partial or total success. After another 8 weeks, 3 out of 6 partial responders converted to total success. Final follow up was done 12 months after the first visit.
This study has a high participation rate of $83 \%$ with only 8 patients who were lost to follow up. The final success rate of Triamcinolone vs manual retraction was $76 \%$ vs $36 \%$ with $p=0.0086$. Triamcinolone appeared to be 2 times more effective than manual retraction using emollient cream. However, after 12 months, recurrence rate of phimosis in steroid group was notable. There were five patients who underwent circumcision due to treatment failure. No significant adverse effect was observed during the study.

The third study by Lund et al. ${ }^{12}$ compared the use of betamethasone $0.1 \%$ cream to aqueous cream in the management of phimosis. One hundred thirty-seven boys were randomised to the treatment $(n=71)$ and control group $(n=66)$. In terms of age, no significant difference was found between both groups. The parents and patients were also carefully instructed to retract the prepuce as much as possible without causing discomfort twice daily. After 4 weeks of treatment, the response was observed. Those who did not respond to initial treatment were offered a further 4 weeks of steroid treatment. There were 14 patients with persistent phimosis that required surgery. At first follow up, the success rate for betamethasone was $74 \%$ compared to $44 \%$ for placebo. At the second follow up, the success rate for betamethasone was $43 / 57$. The final follow-up was done 18 months after the first visit with a dropout of 26 patients, but the author claimed that the number was equal in each group. The overall cure rate was $86 \%$ and only $14 \%$ had minor relapse in which surgery was not necessary. No significant side-effect was found during or after the treatment.

\section{DISCUSSION}

All studies included in this systematic review passed the relevancy criteria based on the similarity of the PICO. In terms of age, samples used in these studies were ranging between 20 months to 15 years (before teenager). The surveys were conducted in different region of the world (Europe, Asia, and North America), hence involving different races. There were also different severity and degree of phimosis patients. The topical steroid used in these studies also varied from mometasone furoate, betamethasone, and triamcinolone which have different potency. However, the follow-up period was somewhat similar, ranging from 4-8 weeks for primary outcome and 12-20 months for final evaluation. The outcome measured was similar.

Despite being carried out in different population with different types of topical steroid, the studies yielded the same result that topical steroid is more effective than other noninvasive treatment in repairing phimosis. There was also no significant 
adverse effect found in these studies. Unfortunately, no study reported the subgroup analysis of steroid efficacy in different age groups though it is necessary to define the best time to use for maximum effect. In 2007 Zampieri et al. ${ }^{13}$ studied the efficacy of topical steroid at different age groups. The result showed that topical steroid is best used at age 4-8 years.

All of the studies that we appraised used placebo as comparison. It can be observed from this research that the placebo effect is observable in the control group. This placebo effect may also be explained by the high variability of population that participated in this study. Further study in the form of meta-analysis must be conducted to compound the effect of each research. Systematic review can also be done to see the impact of this research on these patients.

The steroid has three possible mechanisms to relieve phimosis. ${ }^{14-16}$ First, steroid can cause thinning of the skin and improve the elasticity of the foreskin by decreasing the synthesis of hyaluronic acid, which has an anti-proliferative effect on the epidermis. In addition, topical steroids can inhibit the production of the skin inflammatory mediators, i.e., prostaglandins and leukotrienes. Finally, the lubricant effect of the cream allows boys to retract the foreskin easily.

Since many studies have proved the safety and cost-effectiveness of topical steroid, one should consider choosing steroid as the initial treatment for phimosis. ${ }^{17} \mathrm{~A}$ study by Yilmaz et al ${ }^{18}$ demonstrated the presence of castration anxiety in children undergoing circumcision during their phallic period (age 3-6 years). His study found a significant shift to anxiety in the circumcision group. In this case, topical steroid offers an alternative to avoid pain, complication, and hospitalisation caused by surgery. However, it is important to make sure that the parents and patients follow the instructions carefully and comply with the treatment rule to achieve satisfying outcome.

Despite all the advantages of topical steroid, surgical intervention still holds the key element in some cases of phimosis. It is the obligatory treatment for patients who are resistant to steroid. According to this research, around $5-10 \%$ of these patients are poorly treated with steroid. Yang et al. ${ }^{9}$ said that high-dose steroid is preferable as it has comparable efficacy compared to medium-dosage steroid. Moreover, circumcision is superior in resolving recurrent genitourinary tract infections as it gives more permanent result than noninvasive treatment. The recurrence rate of phimosis after steroid application was notable. In his study, Letendre et $\mathrm{al}^{11}$ explained that recurrence is caused by not performing daily retraction following the completion of the study and inability to maintain hygiene.

It is also important to consider patient's population that may influence the applicability of this research in Indonesia. The limitation of this study is the lack of studies in Asia patients. We believe that genetics plays an important role in this case as retraction of preputium. Similar research in Indonesia should be conducted on the usage of corticosteroid and its effect to relieve retraction.

\section{CONCLUSION}

Topical steroid is effective in reducing the phimosis signs and symptoms, especially in patients who are younger and less than 3 years old. Further study and meta-analysis should be conducted in Indonesia to determine the effectiveness of this therapy in Indonesia.

\section{ETHICAL CLEARANCE}

No ethical clearance is required for this study.

\section{CONFLICT OF INTEREST}

The author reports no conflicts of interest in this work.

\section{FUNDING}

There is no specific funding in making this research.

\section{AUTHOR CONTRIBUTIONS}

All authors conducted literature search, compile the paper, read and approve the final paper, and are responsible for all contain of paper.

\section{REFERENCE}

1. Huang CJ. Problems of the foreskin and glans penis. Clin Ped Emerg Med. 2009. 56-9.

2. Gairdner D. The fate of the foreskin. BMJ. 1949;11: 1433-7.

3. McGregor TB, Pike JG; Leonard MP. Pathologic and physiologic phimosis: approach to the phimotic foreskin. Can Fam Physician. 2007;53(3):445-8.

4. Lundquist ST, Stack LB. Diseases of the foreskin, penis, and urethra. Emerg Med Clin North Am. 2001; 19(3):529-46.

5. Jadad AR, Moore RA, Carrol D, Jenkinson C, Reynolds DJM, Gavaghan DJ, McQuay HJ. Assessing the quality of reports of randomised clinical trials: Is blinding necessary?. Contr Clin Trial. 1996; 17:1-2.

6. Berger VW, Alperson SY. A general framework for the evaluation of clinical trial quality. Rev Recent Clin Trials. 2009;4(2):79-88.

7. Kjaergard LL, Villumsen J, Gluud C. Reported methodologic quality and discrepancies between large and small randomised trials in meta-analyses. Ann Intern Med. 2001; 135(11):982-9. 
8. Elmore JM, Baker LA, Snodgrass WT. Topical Steroid Therapy as an Alternative to Circumcision for Phimosis in Boys Younger Than 3 Years. J Urol. 2002;168(4, Supplement):1746-7.

9. Yang CA, Tsai, YC. Wu, CC. Shih, PL Highly Potent and Moderately Potent Topical Steroids are Effective in Treating Phimosis: A prospective randomized study. Am Urol J. 2005;173:1363-9.

10. Esposito C, Centonze A, Alicchio F, Savanelli A, Settimi A. Topical steroid application versus circumcision in pediatric patients with phimosis: a prospective randomized placebo controlled clinical trial. World J Urol. 2007;26(2):187-90.

11. Letendre J, Barrieras D, Franc-Guijmond J, Abdo A, Houle AM. Topical triamcinolone for persistent phimosis. J of Urol. 2009;182:1759-64.

12. Lund L, Wai KH, Mui LM, Yeung CK. An 18-month follow-up study after randomized treatment of phimosis in boys with topical steroid versus placebo. Scand J of Urol and Nephrol. 2005; 39: 78-81.

13. Zampieri N, Corroppolo M, Zuin V, Bianchi S, Camoglio FS. Phimosis and topical steroids: new clinical findings. Pediatr Surg Int. 2007;23(4):331-335.
14. Chu CC, Chen KC, Diau GY. Topical steroid treatment of phimosis in boys. J Urol. 1999;162(3):861-863.

15. Monsour MA, Rabinovitch HH, Dean GE. Medical management of phimosis in children: our experience with topical steroids. J Urol. 1999;162(3):1162-1164.

16. Kragballe K. Topical corticosteroids: mechanisms of action. Acta Dermatol Venereol. 1989; 151:7-12.

17. Liu J, Yang J, Chen Y, Cheng S, Xia C, Deng T. Is steroid therapy effective in treating phimosis? A meta-analysis. Int Urol Nephrol. 2016; 48(3):335-42.

18. Yilmaz E, Batislam E, Basar MM, Basar H. Psychological trauma of circumcision in the phallic period could be avoided by using topical steroids. Int $\mathrm{J}$ Urol. 2003;10(12):651-656.

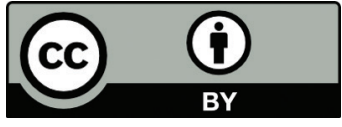

This work is licensed under a Creative Commons Attribution 